\title{
Reflections of a 26-Year Cancer Survivor
}

\section{Opinion}

Cancer, the very word strikes fear in the heart because of its strong association with helplessness, suffering and death. When I found a pea-sized lump in my breast in 1991, terror gripped my heart. I intuitively knew the lump was malignant and that it spelled a painful death in the near future. In that moment, time stood still. I saw a war within my heart: my 42-year-old body was terrified of losing its physical form, but my ageless soul longed to go home to rest in the World of Light. Ever since I had been molested at age nine, I had been thinking that being in heaven would be a lot more fun than living on this violent planet. And in that moment of timestanding-still, I changed my mind. I decided to stay. I thanked the Universe for sending me the ticket to heaven I had been yearning for, but now that I was looking at this particular ticket in my hand, I was not really in such a big hurry. Three months earlier, I had married my second husband after being single for 12 years, and I wanted some time with him.

\section{Touched by the Divine}

The night before surgery to remove the malignant tumor, I was meditating and praying for strength to go through whatever lay ahead. In my mind, the Lord Jesus Christ appeared dressed in a long flowing purple robe. (Jesus is the face that Divine energy wears for me, as I was raised in a Christian church. For other people, a different figure might represent the most love they could imagine feeling.) Jesus lightly touched my heart center saying, "I now heal your soul." Instantly, I felt a wound heal up that had been in my heart since before I was born. And in that moment, I knew that with my soul healed, my body would follow suit and survive the illness. Now, twenty-six years later, I am cancer-free and in radiant health. I am filled with gratitude for my life and for all that I learned through the cancer experience. I love my body and appreciate the service my body provides of housing my spirit for the time I am here. I marvel at the intricacy of experience as a human being.

\section{The miracle of birth}

A miracle happened in my life after I recovered from cancer: my daughter gave birth to a baby girl. I was present at the birthing of this first grandchild and saw her red hair coming down the birth canal five minutes before she was born. She crowned, then the first precious little ear appeared, then the head popped out, full of wide-eyed astonishment, and then the whole wonderful little body tumbled out. She was angry and yelling about being kicked out of her water bed, but we were overjoyed to welcome her into our hearts!

The motherline bond that came with my daughter having a daughter is inexpressibly delightful. My daughter had been apprehensive about the process of giving birth. So on my daughter's birthday, two months before my granddaughter's birth, I did a regression with my daughter to go back and remember her own birth. As she recalled the womb getting tight, and then squeezing her down the birth canal, she exclaimed, "Angels are all around! Some of them are your angels and some are mine. And

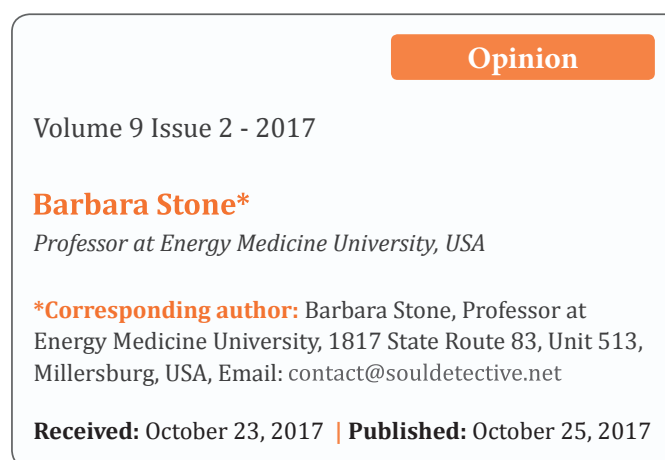

your grandfather is here too!" I felt the presence of angels at the birth of my grandchild and wondered whether my Grandfather was there again, also watching the miracle. Now I have five grandchildren, and they bring great joy into my life. I would have missed all of them if I had died from the cancer. Leaving life in my 40 s would have been like leaving a banquet after the appetizers to go back home and missing the main course!

\section{Pregnancy dreams}

During the nine months before my diagnosis of cancer, I kept dreaming I that I was pregnant and then that I had a baby. The dream reality of giving birth was so vivid, so much more intense than my waking reality, that in another dream, I wrote to the gynecologist who had done a tubal ligation on me in my 20s to tell him the operation had been a flop! Curiously, the way a malignant tumor hides from the immune system is to mimic the chemistry of a baby. Ordinarily, the immune system wipes out any lump that is growing too fast, but babies are exempt because they are supposed to double their size rapidly.

So cancer was my baby, a new life growing within me, turning my world upside-down and giving me a brand new outlook on the dynamics between the different layers of who I am: physical body, energy body, emotional body, mental body, and spiritual body. After my first radiation treatments, I fell into a pit of depression. I felt like I wanted to die and for God to take me quickly, before the chemotherapy. The physical trauma of the Western medical treatments impelled me to explore avenues of complementary medicine to restore my health. Osteopathic cranial-sacral treatments during radiation helped restore proper energy flow in my body. Acupuncture during chemotherapy revived organ systems that were overtaxed by excreting the therapeutic poisons which killed cancer cells. Between rounds of chemotherapy, a healer helped me release the emotional wound of being molested by using the spiritual tool of forgiveness, and my heart healed.

\section{Thought Field Therapy (TFT)}

I began to view the clients I was seeing in my psychotherapy practice from a different perspective. I saw an advertisement for a new psychotherapy called Thought Field Therapy (TFT) with a banner across the top boldly stating, "There is a cure." I laughed, wondering what kind of gimmick that was and how 
much they charged for the workshop. But I saved the ad. Later, when a colleague highly recommended the training, I sent for the information and received an article by the instructor outlining a series of four points on the acupuncture meridians to tap in sequence to release trauma. I called a traumatic incident to mind and tapped on the four points. To my astonishment, the trauma disappeared. I still had the memory, but it no longer produced disturbing feelings. I could not believe what I had just experienced, but I knew how powerful the meridian system was from my experience of getting acupuncture during chemotherapy. I immediately signed up for the training.

Thought Field Therapy changed my life by giving me tools to release my emotional baggage. Now I teach others these tools to quickly release negative emotions. My oncologist fired me in 1996, telling me our work together was finished. When I turned 50 in 1998, I took up belly dancing, which opened up a delightful new relationship with the physical aspect of my being. Most of the time, I forget that I had cancer because I am so busy with my life. I developed a method bridging Energy work and Shamanism that I call "Soul Detective," and I teach my students to do things with energy work that have been traditionally done by shamansreleasing entities, crossing earthbound spirits, and retrieving lost soul parts. I have time to work in my perennial flower beds and my organic garden. I remarried again last year, and I treasure my relationship with my wonderful husband, family, and friends.

\section{Gratitude}

The more I work with energy and see how my thoughts affect my feelings and my physical body, the more I integrate all the levels of who I am. I am so grateful to Spirit for giving me this chance to really enjoy being here on earth before the time comes when I will go into the next world. At age 68 , I ran a $5 \mathrm{~K}$ race this month and finished in 36 minutes, placing \#263 out of over 600 runners. I am very pleased to be in good shape, and I love my body and my life. I am no longer in such a rush to get to Heaven!

\section{Biography}

Barbara Stone, PhD, LISW, is the author of Cancer As Initiation: Surviving the Fire (1994, Open Court Publishing Co., LaSalle, IL), Invisible Roots: How Healing Past Life Trauma Can Liberate Your Present (2008, Energy Psychology Press, Santa Rosa, CA), and Transforming Fear into Gold (2012, The Indigo Connection, Strongsville, $\mathrm{OH}$ ). 